\title{
Milk production and dry matter intake of lactating Holstein cows fed low fiber diets in the tropics ${ }^{1}$
}

\author{
Teodoro M. Ruiz ${ }^{2}$, Jaime Moyá $a^{3}$ and Luis Viera ${ }^{4}$
}

J. Agric. Univ. P.R. 84(1-2):17-28 (2000)

\begin{abstract}
Three stargrass silage (SGS)-based diets formulated to contain 20, 26 and $32 \%$ neutral detergent fiber (NDF) were compared as to their effect on dry matter intake (DMI) and milk production. Twelve lactating Holstein cows averaging 110 days in milk were arranged in four replications of a $3 \times 3$ Latin Square design. Treatments did not affect DMI or DMI as percentage of body weight (BW); mean values for these parameters were $15.4 \mathrm{~kg} / \mathrm{cow} /$ day and $3.06 \%$, respectively. However, cows consuming $32 \%$ NDF diet had a tendency toward lower $(8.6 \%)$ intake of organic matter (OM) as percentage of BW than cows on the $20 \%$ NDF diet. Intake of NDF as a percentage of BW increased $(P<0.01)$ linearly $(0.62$ to $0.93 \%)$ as dietary NDF concentration increased. Milk production averaged $21.0 \mathrm{~kg} / \mathrm{cow} / \mathrm{day}$ and was not affected by dietary treatment. Reducing dietary NDF from 32 to $20 \%$ resulted in a reduction $(P<0.01)$ in milk fat from 3.09 to $2.66 \%$. This reduction resulted in a 1.3 $\mathrm{kg} /$ cow/day increase $(P<0.05)$ in $3.25 \%$ fat-corrected milk $(3.25 \% \mathrm{FCM})$ as the percentage of dietary NDF increased. Gross efficiency of energy $\left(N_{L}\right)$ use for milk production and $3.25 \%$ FCM increased linearly with dietary NDF by 9.7 and $17.3 \%$, respectively. Results point out that for mid-lactation cows at the observed level of production, diets lower than $32 \%$ NDF will not result in higher DMI and milk production, and will be less efficient in the use of energy for milk production.
\end{abstract}

Key words: dairy cows, grass silage, neutral detergent fiber

\section{RESUMEN}

Producción de leche y consumo de materia seca de vacas Holstein en lactación consumiendo dietas bajas en fibra en el trópico

Se compararon tres dietas basadas en ensilaje de yerba estrella formuladas para contener 20,26 y $32 \%$ de fibra detergente neutro (FDN) para evatuar su efecto sobre el potencial de consumo de materia seca (MS) y producción de leche de vacas Holstein a media lactancia (110 días). Las vacas se asignaron a tratamientos de acuerdo con un diseño de cuadrados latinos de $3 \times 3$, replicado cuatro veces. Los tratamientos no tuvieron efecto sobre el consumo de MS y MS a base del porcentaje de peso vivo (PV) de la vaca; los promedios generales fueron $15.4 \mathrm{~kg} / \mathrm{vaca} / \mathrm{dia}$ y $3.06 \%$ del $\mathrm{PV}$, respectivamente.

'Manuscript submitted to Editorial Board 17 September 1999.

${ }^{2}$ Assistant Researcher, Department of Animal Science, Univ. of Puerto Rico-Mayagüez, P.O. Box 9030, Mayagüez, PR 00680-9030.

${ }^{3}$ Assistant Researcher, Department of Animal Science.

"Research Assistant, Agricultural Experiment Station, Gurabo. 


\begin{abstract}
Sin embargo, las vacas que consumieron la dieta con $32 \%$ FDN exhibieron una tendencia a un menor $(8.6 \%)$ consumo de materia orgánica (MO) como porcentaje del PV comparado con la dieta con $20 \%$ FDN. El consumo de FDN como un porcentaje del PV aumentó $(P<0.01)$ linealmente de 0.62 a $0.93 \%$ según aumentó la concentración de FDN. El promedio de producción de leche fue $21.0 \mathrm{~kg} / \mathrm{vaca} / \mathrm{dia}$ y éste no se afectó por los tratamientos. La reducción de 32 a $20 \%$ en la concentración de FDN resultó en una reducción $(P<$ 0.01 ) en la concentración de grasa láctea de 3.09 a $2.66 \%$. Como resultado hubo un aumento de $1.3 \mathrm{~kg} / \mathrm{vaca} /$ dia en la producción de leche corregida al $3.25 \%$ de grasa, según aumentó el FDN de 20 a $32 \%$. Al aumentar la concentración de FDN de 20 a $32 \%$ la eficiencia de la utilización de la energía $\left(N_{L}\right)$ para la producción de leche y leche corregida al $3.25 \%$ de grasa se incrementó en un $9.7 \%(P<0.05)$ y $17.3 \%(P<0.01)$, respectivamente. Según los resultados de este estudio a los niveles de producción observados, las dietas con menos de $32 \%$ de FDN no tendrán un efecto sobre el consumo de MS ni sobre la producción de leche integra, aún cuando estas dietas resultan en un mayor consumo de energia. Además, estas dietas son menos eficientes en el uso de energia para la producción de leche.
\end{abstract}

\title{
INTRODUCTION
}

It can be argued that low dry matter intake (DMI) is the main factor limiting milk production of dairy cows in the tropics (Ugarte et al., 1983). In a tropical environment, high temperatures and humidity combine not only to reduce appetite but also to reduce milk production efficiency in lactating cows (National Academy Press and National Research Council, 1981). Relative to thermoneutrality (18 to $20^{\circ} \mathrm{C}$ ), at $35^{\circ} \mathrm{C}$ the expected DMI decreases by about $8 \%$, while maintenance requirements are increased by about $20 \%$. These two facts in conjunction are mainly responsible for the large reduction (33\%) in milk production observed at the higher temperature.

It follows that feeding management in the tropics should be directed toward maximizing feed consumption if the genetic potential of the lactating Holstein cows is to be fully realized. Mertens (1989) has suggested the possibility of increasing DMI and milk production of dairy cows by manipulating the concentration of neutral detergent fiber (NDF) in the diet. This procedure was demonstrated in a study where Holstein cows were fed Bermuda grass silage-based diets containing 46, 41.2, 36.6 or $31.8 \%$ NDF (Bernal, 1992). In this study, DMI was found to increase linearly with a reduction in dietary NDF. In addition, feed intake was $36.7 \%$ higher on the diet with the lowest NDF compared to that with the highest NDF concentration. Similarly, the difference in milk production was $17.2 \%$ higher in the low NDF diet. Furthermore, Ruiz (1993) indicated that diets with NDF concentrations below $30 \%$ result in additional DMI and milk production improvements. The purpose of this study was to investigate the possibility that low fiber diets, below $30 \%$ NDF, could influence positively the DMI and milk production of lactating Holstein cows in the tropics. 


\section{MATERIALS AND METHODS}

The experiment was conducted at the Gurabo Substation dairy farm of the University of Puerto Rico Agricultural Experiment Station, 115 meters above sea level. It lasted 68 days, from 24 June to 31 August, 1998. Mean environmental temperature at the site fluctuated from a daily minimum of $20.9^{\circ} \mathrm{C}$ to a maximum of $33.0^{\circ} \mathrm{C}$ during the experiment, whereas fluctuations in daily maximum air temperature were from 31.7 to $34.4^{\circ} \mathrm{C}$.

A stargrass (Cynodon nlemfuensis) plot used for grazing lactating cows was given a standardizing cut and fertilized with approximately $400 \mathrm{~kg} / \mathrm{ha}$ of a 15-5-10 fertilizer. The grass was harvested in early May at 44 days of regrowth and cut to a stubble height of $15 \mathrm{~cm}$. Mean particle size of the chopped grass was about $5 \mathrm{~cm}$. It was then ensiled in a bag silo (Ag Bag Corp., Astoria, OR) ${ }^{6}$ approximately $2.3 \mathrm{~m}$ in diameter and remained ensiled for at least 40 days before the silo was opened.

Twelve lactating Holstein cows, between 99 and 136 days-in-milk at the start of the trial, were arranged according to a $3 \times 3$ Latin Square Design with four replications. Treatment arrangement for each pair of replicate squares was balanced to account for residual effects. One replication consisted of primiparous cows and the other three contained multiparous cows at similar stages of lactation. Each experimental period was 24 days, with 14 days for adaptation to the dietary treatments and 10 days for data collection. However, the last two data collection periods were shortened to eight days because of a projected silage insufficiency.

Cows were housed in an open-sided barn with a concrete floor and fitted with Calan gates (American Calan Inc., Northwood, $\mathrm{NH}$ ) to allow the measurement of individual feed intake. They remained in the barn throughout the day, except when removed for milking: Experimental cows were milked every day at 04:00 and 15:30 h, and milk yield was recorded in calibrated glass jars at each milking. Samples for milk composition analyses were collected from four consecutive milkings within the last three days of each data collection period. Milk was analyzed for protein and fat contents by the Puerto Rico Dairy Herd Improvement Association Laboratory (Dorado, P.R.). Body weights were recorded at 06:00 h immediately after milking for two consecutive days, two days prior to the start of Period I and during the last two days of each of the

\footnotetext{
${ }^{5}$ Trade names in this publication are used only to provide specific information. Mention of a trade name does not constitute a warxanty of equipment or materials by the Agricultural Experiment Station of the University of Puerto Rico, nor is this mention a statement of preference over other equipment or materials.
} 
three experimental periods. Milk yield was standardized to $3.25 \%$ fat, which is considered more relevant than $4 \%$ fat for a market where no additional payment is made for butterfat. The formula used for $3.25 \%$ fat corrected milk ( $3.25 \% \mathrm{FCM})$ was as follows:

(milk fat yield in $\mathrm{kg} \times 16.899)+(0.4508 \times$ milk yield in $\mathrm{kg})$.

Treatment diets were formulated to $20 \%, 26 \%$ and $32 \%$ NDF on a dry matter (DM) basis. They consisted of mash concentrate feeds and stargrass silage (SGS), and were formulated to be isonitrogenous. Both SGS and concentrate were weighed on a portable scale and mixed daily by hand prior to feeding. The ration was offered twice daily at $06: 30$ and 17:00 $\mathrm{h}$ in amounts that allowed 10 to $15 \%$ orts on an as-fed basis. Total amount consumed and orts were recorded daily for each cow. The proportions of ingredients in the diet were kept constant on a DM basis by monitoring SGS and concentrates for DM twice weekly. Samples of SGS and of the three concentrates were collected weekly and kept frozen until composited for each experimental period. Composite samples were oven dried to a constant weight at $55^{\circ} \mathrm{C}$ for a minimum of 48 hours. Composite samples were analyzed chemically by the Northeast DHIA Forage Laboratory (Ithaca, NY).

Data were analyzed by least squares ANOVA using the general linear model procedures of SAS (Littell et al., 1992). Differences among treatments were analyzed by the use of contrasts.

\section{RESULTS AND DISCUSSION}

The SGS used had a characteristic acid smell typical of well-preserved silage. It exhibited minimal spoilage in the feed bunk and throughout the trial appeared stable under aerobic conditions. However, no chemical or aerobic stability analyses of the silage were conducted. Chemical composition of SGS (Table 1) can be considered typical of a tropical grass of medium maturity. In vitro true digestibility was $54.6 \%$, and was similar to the estimated total digestible nutrient (TDN) content $(55.6 \%)$ obtained from chemical laboratory analyses. However, crude protein (CP) content was lower than expected for a well fertilized grass and nearly $20 \%$ lower than that of the fresh stargrass forage prior to ensiling.

Table 2 presents the ingredients and chemical composition of the diets. The three concentrate mixtures used were based mainly on corn and soybean meal. Use of wheat middlings (high NDF by-product feed) was minimized to maintain NDF concentration of the concentrates below $10 \%$. Experimental diets were formulated to be isonitrogenous; however, lower $\mathrm{CP}$ concentration in the $32 \%$ NDF diet was mainly due 
TABLE 1.-Average chemical composition, on a dry matter (DM) basis, of stargrass silage used to formulate experimental diets.

Chemical composition, \% of DM

$\begin{array}{lc}\mathrm{DM}, \% & 30.8 \\ \mathrm{CP} & 7.4 \\ \mathrm{NDF} & 77.4 \\ \mathrm{ADF} & 56.2 \\ \mathrm{Ca} & 0.26 \\ \mathrm{P} & 0.19 \\ \mathrm{~K} & 1.45 \\ \mathrm{Mg} & 0.13 \\ \mathrm{Na} & 0.04\end{array}$

In vitro true digestibility, \%

56.4

to the lower than expected CP of the SGS and the higher content of silage in this diet.

Actual NDF concentrations $(20.2,26.2$, and $31.9 \%)$ of the experimental diets were similar to expected values $(20,26$, and $32 \%)$. Silage contributed $59.3,72.5$, and $78.4 \%$ of the total dietary NDF to the 20,26 and $32 \%$ NDF diets, respectively (Table 2). As formulated, the 20 and 26\% NDF diets are considered outside current National Research Council (NRC, 1988) recommendations that $75 \%$ of dietary NDF should be from the forage portion of the diet. On the other hand, only the $20 \%$ diet falls below the recommended dietary minimum of $25 \%$ total NDF (NRC, 1988).

Current (1998) NRC guidelines state that diets having greater than $70 \%$ concentrate are inadequate for normal ruminal fermentation. Diets with 20 and $26 \%$ NDF exceed this maximum recommendation, with forage to concentrate ratios below 30:70 (Table 2). Only the $32 \%$ NDF diet was within this recommended limit, with forage to concentrate ratio of 32:68. However, it is not clear whether the NRC's recommendation strictly applies to diets based on tropical forages, which are much higher in fiber than grasses and legumes from temperate zones. In general, forage to concentrate ratios of diets based on tropical grasses are lower than those typically observed for diets based on corn silage and other temperate forages (Bernal, 1992; Ruiz et al., 1995a). Net energy for lactation $\left(\mathrm{NE}_{\mathrm{L}}\right)$ in the diet was estimated from the $\mathrm{ADF}$ analysis using the NRC equation (1988). It decreased from 1.87 to $1.75 \mathrm{Mcal}-\mathrm{NE}_{\mathrm{L}} / \mathrm{kg}$ DM as dietary NDF concentration increased. This difference can be largely accounted for by the higher concentration of SGS in the total diet as NDF increased. 
TABLE 2.-Ingredients and chemical composition of experimental diet formulated to three neutral detergent fiber (NDF) concentrations.

\begin{tabular}{lccc}
\hline & \multicolumn{3}{c}{ NDF in diet DM } \\
\cline { 3 - 4 } & $20 \%$ & $26 \%$ & $32 \%$ \\
\hline Ingredient composition, \% DM & & & \\
Stargrass silage & 15.5 & 24.6 & 32.3 \\
Ground corn & 62.8 & 53.5 & 43.4 \\
Soybean meal & 18.0 & 18.2 & 17.8 \\
Wheat midds & 1.6 & 1.6 & 4.3 \\
Mineral mixture & 2.1 & 2.1 & 2.2 \\
Forage:Concentrate ratio & $15: 85$ & $25: 75$ & $32: 68$ \\
Chemical composition, \% DM & & & \\
DM, \% & & & \\
OM & 68.5 & 60.5 & 55.2 \\
CP & 95.5 & 93.9 & 94.1 \\
NDF & 16.7 & 16.5 & 15.8 \\
ADF & 20.2 & 26.2 & 31.9 \\
Ca & 11.9 & 17.3 & 21.7 \\
P & 0.79 & 0.81 & 0.83 \\
Mg & 0.45 & 0.47 & 0.47 \\
K & 0.40 & 0.41 & 0.35 \\
Na & 0.96 & 1.04 & 1.11 \\
Forage NDF as a percentage of diet NDF & 0.32 & 0.38 & 0.32 \\
\hline Energy density & 59.3 & 72.5 & 78.4 \\
Mcal-NE / kg of DM & 1.87 & 1.81 & 1.75 \\
\hline
\end{tabular}

${ }^{N E_{L}}$ calculated from ADF analysis using the NRC (1988) equation.

Dietary treatment had no effect on DMI or DMI as a percentage of body weight (DMIBW) of cows consuming the experimental diets (Table 3). Mean DMI and DMIBW were $15.4 \mathrm{~kg} / \mathrm{cow} /$ day and $3.06 \%$ of $\mathrm{BW}$, respectively. Organic matter (OM) intake was not different among treatments; however, there was a tendency $(\mathrm{P}=0.106)$ for increased intake of OM on a percentage of BW (OMBW) basis as NDF in the diet declined. Cows consumed $8.6 \%$ less OMBW on the $32 \%$ NDF diet than on the $20 \%$ NDF diet. On the other hand, differences in the energy concentration of the diets resulted in a linear $(P<0.05)$ increase in $\mathrm{NE}_{\mathrm{L}}$ intake as dietary NDF concentration declined. In all diets, energy intake was sufficient to meet the recommended daily nutritional requirements. Energy intake was 9.7 and 14\% higher for the 26 and $20 \% \mathrm{NDF}$ diets than for the $32 \% \mathrm{NDF}$ diet. 
TABLE 3.-Least squares means for intakes of $D M, O M, C P, A D F, N D F$ and $N E_{I .}$ by lactaling cows fed diets baserl on stargrass silage and formulated to contain 20,26 and $32 \% N D F$.

\begin{tabular}{lcccc}
\hline & \multicolumn{4}{c}{ NDF in diet DM } \\
\cline { 2 - 5 } & $20 \%$ & $26 \%$ & $32 \%$ & $\mathrm{SE}$ \\
\hline Intake, \% BW & & & & \\
$\mathrm{DM}$ & 3.09 & 3.10 & 2.89 & 0.11 \\
$\mathrm{OM}$ & 3.02 & 2.97 & 2.76 & 0.10 \\
NDF' & 0.62 & 0.81 & 0.93 & 0.03 \\
Intake, kg/d & & & & \\
DM & 15.7 & 15.6 & 14.7 & 0.61 \\
OM & 15.3 & 14.9 & 14.0 & 0.56 \\
CP' & 2.6 & 2.6 & 2.3 & 0.10 \\
ADF' & 1.9 & 2.7 & 3.2 & 0.08 \\
NDF $^{\prime}$ & 3.2 & 4.1 & 4.7 & 0.14 \\
\hline NE $_{1,2}$ Mcal/day & 29.3 & 28.2 & 25.7 & 1.12 \\
\hline
\end{tabular}

Linear increase with increasing concentration of $\mathrm{NDF}(\mathrm{P}<0.01)$.

"Quadratic decrease with increasing concentration of NDF $(\mathrm{P}<0.01)$.

"Linear decrease with increasing concentration of NDF $(P<0.05)$.

Dry matter iriake was far lower than achievable levels (3.5 to $4.0 \%$ of $\mathrm{BW}$ ) by high producing Holstein cows (NRC, 1988). In this trial, cows consumed 31.6 and $20.8 \%$ less DMI and DMIBW, respectively, than cows consuming a $31.8 \%$ NDF diet based on Bermudagrass silage (Bernal, 1992) under conditions of low humidity and low environmental temperatures. Compared with intake at temperatures around $5^{\circ} \mathrm{C}$, at $35^{\circ} \mathrm{C}$ there should be a reduction of DMIBW of nearly $2 \%$ (National Academy Press and National Research Council, 1981). The lower than expected DMI of all cows in this trial might be attributed in part to the high humidity as well as to the high temperatures prevailing. In addition, the high intake of $\mathrm{NE}_{\mathrm{L}}$ relative to requirements, particularly for the 20 and $26 \%$ NDF diets, could have resulted in metabolic (energy) limitations on $\mathrm{DMI}$ and could have prevented higher $\mathrm{IM} \mathrm{M}$ consumption by the cows.

Contrary to energy intake, CP intake was just enough to meet requirements for production. For cows consuming the $32 \%$ NDF diet, protein intake appears to have been insufficient, and lower $(\mathrm{P}<0.01)$ than for the other two diets. Consumption of CP for these cows was about $8 \%$ below the daily requirements necessary to meet production and maintenance needs (NRC, 1988). This reduction was the result of a lower than expected concentration of $\mathrm{CP}$ in the diet. 
Dietary treatments had their greatest effect on acid detergent fiber $(\mathrm{ADF})$ intake (Table 3$)$. There was a linear increase $(\mathrm{P}<0.01)$ with the increase in dietary NDF. Cows on the $20 \%$ NDF diet consumed $40.6 \%$ less ADF than cows on the $32 \%$ NDF diet. As a result, the $20 \%$ NDF diet was well below the minimum ADF recommendation of $16 \%$ of the total diet (NRC, 1988). This large difference between the high and low NDF diets could be caused by the higher ADF:NDF ratio in SGS compared with that in the concentrate and to the higher percentage of silage in the $32 \%$ NDF diet.

As expected, NDF intake increased linearly $(\mathrm{P}<0.01)$ with the NDF concentration in the diet. Cows on the $20 \%$ NDF diet consumed $31.9 \%$ less NDF than cows on the $32 \%$ NDF diet. Similarly, NDF intake as percentage of $\mathrm{BW}$ increased linearly $(\mathrm{P}<0.01)$ from 0.62 to $0.93 \%$ as dietary NDF increased from 20 to $32 \%$, even though NDF intake from the $32 \%$ NDF diet was lower than that reported by Ruiz et al. (1995a) for cows receiving similar diets. Guidelines for NDF intake from forages compiled by Varga et al. (1998) recommend that minimum forage NDF intake should be $0.85 \%$ of $\mathrm{BW}$ when 1.1 - to $1.2 \%$-units of total diet NDF is provided by grains or starchy ingredients. According to these guidelines, all diets in this trial were below minimum recommended levels. The 32\% NDF diet had the highest percentage of NDF from forage (78.4\%), yet the mean forage NDF intake was only $0.73 \%$ of BW. This might indicate that fill capacity of the cows was never reached or that at the level of milk production and stage of lactation of the cows, energy was controlling intake below the fill capacity of the cows. The most plausible answer, as mentioned before, is that intake was controlled by energy satiation. Particularly in the case of the 20 and $26 \%$ NDF diets, estimated energy intake for these can easily exceed requirements for production and maintenance.

The increase in $\mathrm{NE}_{\mathrm{L}}$ intake did not result in an increase in milk production when the 20\% NDF diet was fed (Table 4). Mean milk production was $21 \mathrm{~kg} / \mathrm{cow} /$ day across all dietary treatments. Diets did not influence milk protein content, and the overall mean was $3.04 \%$. Mean milk protein concentration appears normal for dairy cows consuming this type of diet (Ruiz et al., 1995b). On the other hand, milk fat percentage increased linearly $(\mathrm{P}<0.01)$ as NDF concentration increased from 20 to $32 \%$ of DM. Milk fat concentration was $13.9 \%$ lower for the $20 \%$ NDF diet than for the $32 \%$ NDF diet. Perhaps this finding is an indication of a less favorable ruminal environment which could in the long run have negative consequences on the health and productivity of the cows (Ugarte et al., 1983). As a result of the lower fat concentration, production of $3.25 \%$ FCM increased $(\mathrm{P}<0.05)$ linearly as NDF concentration in the diet increased. Yield of $3.25 \%$ FCM was 
TABLE 4,-Least squares means for milk production, $3.25 \%$ fat corrected milk (FCM) and milk composition for lactating cows fed diets based on stargrass silage and formulated to 20,26 and $32 \% N D F$.

\begin{tabular}{lcccc}
\hline & \multicolumn{4}{c}{ NDF in diet DM } \\
\cline { 2 - 5 } & $20 \%$ & $26 \%$ & $32 \%$ & $\mathrm{SE}$ \\
\hline Actual milk, kg/d & 21.0 & 21.0 & 21.0 & 0.30 \\
$3.25 \% \mathrm{FCM}, \mathrm{kg} / \mathrm{d}^{\prime}$ & 19.0 & 19.9 & 20.3 & 0.32 \\
Milk fat, \% $^{2}$ & 2.66 & 2.98 & 3.09 & 0.09 \\
Milk protein, \% & 3.05 & 3.04 & 3.01 & 0.04 \\
\hline
\end{tabular}

'Linear increase with increasing concentration of NDF $(\mathrm{P}<0.05)$.

${ }^{2}$ Linear increase with increasing concentration of NDF $(P<0.01)$.

$6.4 \%(1.3 \mathrm{~kg} / \mathrm{cow} / \mathrm{d})$ lower when cows consumed the $20 \%$ NDF diet rather than the $32 \%$ NDF diet. This decrease occurred despite higher energy and crude protein intake by cows consuming the $20 \%$ NDF diet.

There was a tendency $(\mathrm{P}=0.117)$ toward increased weight loss as NDF concentration increased from 20 to $32 \%$ (Table 5). The $20 \% \mathrm{NDF}$ diet was the only one that showed weight gain; however, differences were not statistically significant. Mean weight change across all diets was $-0.086 \mathrm{~kg} / \mathrm{cow} /$ day. Cows consuming $20 \%, 26 \%$ and $32 \% \mathrm{NDF}^{\mathrm{ra}} \mathrm{ra}$ tions produced $1.6,1.8$ and $2.1 \mathrm{~kg}$ of actual milk per kilogram of concentrate consumed, respectively. These amounts represent an improvement of $32.5 \%$ and $17.7 \%$ when cows consumed the $32 \%$ NDF diet

TABLE 5.-Efficiency of concentrate use and gross efficiency of energy ${ }^{\prime}$ use for milk yield (MY) and fat corrected milk (FCM), and least square means for body weight change.

\begin{tabular}{|c|c|c|c|c|}
\hline & \multicolumn{4}{|c|}{ NDF in diet DM } \\
\hline & $20 \%$ & $26 \%$ & $32 \%$ & $\mathrm{SE}$ \\
\hline $\begin{array}{l}\text { Mean change in body weight, } \\
\mathrm{kg} / \mathrm{cow} / \mathrm{day}\end{array}$ & 0.12 & -0.13 & -0.46 & 0.25 \\
\hline $\begin{array}{r}\text { Efficiency of concentrate use }{ }^{2} \\
\text { kg-milk/kg-concentrate DM }\end{array}$ & 1.64 & 1.82 & 2.12 & 0.06 \\
\hline $\begin{array}{l}\text { Gross efficiency of energy for } \mathrm{MY}^{3} \text {, } \\
\mathrm{kg} \text {-milk/Mcal-NE } \mathrm{N}_{\mathrm{L}} \text { intake }\end{array}$ & 0.74 & 0.76 & 0.82 & 0.026 \\
\hline $\begin{array}{l}\text { Gross efficiency of energy for } \mathrm{FCM}^{2} \text {, } \\
\mathrm{kg}-3.25 \% \mathrm{FCM} / \mathrm{Mcal}-\mathrm{NE}_{\mathrm{t}} \text { intake }\end{array}$ & 0.67 & 0.72 & 0.81 & 0.022 \\
\hline
\end{tabular}

${ }^{\prime} \mathrm{NE}_{6}$ calculated from $\mathrm{ADF}$ analysis using the $\mathrm{NRC}(1988)$ equation.

'Linear increase with increasing concentration of NDF' $(P<0.01)$.

3Linear increase with increasing concentration of NDF $(P=0.073)$. 
rather than the 20 or $26 \% \mathrm{NDF}$ diet, respectively. On the basis of the reduction in milk fat, lack of a response in milk yield, and current NRC recommendations for minimum NDF concentrations ( 25 to $28 \%$ of DM) in diets of lactating cows, the $20 \% \mathrm{NDF}$ diet could appear extreme. However, this type of diet is very common among dairy farmers in Puerto Rico. In a recent survey ${ }^{6}$ of 205 dairy farms on the island, over $80 \%$ had efficiencies of concentrate use for milk production that were lower than $1.6 \mathrm{~kg}$ of milk/kg of concentrate DM fed, with a mean of only 1.23 .

Similarly, efficiency of DMI for milk production showed a linear decline $(\mathrm{P}<0.05)$ from 1.43 to 1.30 to $1.25 \mathrm{~kg}$ of $3.25 \% \mathrm{FCM} / \mathrm{kg} \mathrm{DMI}$ as NDF concentration declined from 32 to 26 to $20 \%$. Despite the fact that diets low in fiber had higher energy density and cows on these diets consumed more total $\mathrm{NE}_{\mathrm{t}}$, this did not translate into more milk production or higher production efficiency. Gross efficiency of energy utilization for milk production ( $\mathrm{kg}$ millk/ $\mathrm{Mcal} \mathrm{NE}$ intake) was reduced linearly $(\mathrm{P}=0.07)$ by $9.7 \%$ as the NDF concentration in the diet declined from 32 to $20 \%$. When milk production was standardized to $3.25 \%$ FCM efficiency reduction was more pronounced $(\mathrm{P}<0.01)$. Gross efficiency of energy for $3.25 \% \mathrm{FCM}$ production was $17.3 \%$ lower when cows consumed the $20 \%$ NDF diet than with the $32 \%$ NDF diet.

Determining relative costs (Table 6) can be another means of measuring the efficiency of the diets. Estimated cost of the 20\% NDF diet was 2.2 cents $/ \mathrm{kg}$ DM more than for $32 \% \mathrm{NDF}$ diet. For all diets, relative cost of concentrate feeds represented an extremely large portion of the total cost of the diet. Cost of concentrate increased from 82 to 87 to $92 \%$ of the total cost of the ration as dietary NDF declined from 32 to 26 to $20 \%$. Total ration cost was 55 cents per cow more for the $20 \%$ NDF diet than for the diet containing $32 \%$ NDF. Feed cost per kg of milk produced was 2.6 cents $/ \mathrm{kg}$ DM more with the $20 \%$ NDF diet than with the $32 \% \mathrm{NDF}$ diet. For a herd averaging $21 \mathrm{~kg}$ milk/cow/day and consuming a diet similar to $20 \% \mathrm{NDF}$, this would represent $\$ 200.75 /$ cow/year more in feed costs than for a cow consuming a diet similar to a $32 \%$ NDF diet. For a 100-cow herd, this is equivalent to $\$ 20,075$ more in total feed costs in a year without achieving any advantage in milk production.

In spite of being lower in bulk (NDF) and higher in energy concentration than a diet containing $32 \% \mathrm{NDF}$, an unbalanced diet low in fiber ( 20 or $26 \%$ NDF) will not result in higher milk production at the level of production achieved in this trial for cows in mid-lactation. It appears that the 20 and $26 \%$ NDF diets limited intake through metabolic mechanisms. The low fiber intake was below and the high energy intake above requirements, thus supporting this conclusion.

6Ruiz, T. M., M. López-Beníquez and R. Macchiavelli, 1999. Unpublished data. 
TABLE 6.-Relative costs (U.S. dollars) of diet, stargrass silage (SGS) and concentrate, and total daily cost of ration for each of the experimental diets.

\begin{tabular}{llll}
\hline & \multicolumn{3}{c}{ NDF in diet DM } \\
\cline { 2 - 4 } & $20 \%$ & $26 \%$ & $32 \%$ \\
\hline Relative cost of the diet, $\$ / \mathrm{kg}^{-1}$ & 0.232 & 0.220 & 0.210 \\
Cost of SGS consumed, $\$ /$ day & 0.29 & 0.46 & 0.57 \\
Cost of concentrate consumed, $\$$ day & 3.36 & 2.98 & 2.53 \\
Cost of the ration, $\$ /$ day/cow & 3.65 & 3.44 & 3.10 \\
\hline
\end{tabular}

${ }^{1}$ Assumes cost of concentrate and stargrass silage of 25.3 and 12.1 cents $/ \mathrm{kg}$ of DM, respectively.

"Calculated by multiplying intake of DM by cost $/ \mathrm{kg}$.

For cows producing less than $21 \mathrm{~kg}$ of milk/day, a diet having $32 \%$ NDF or higher is recommended instead of those with lower NDF concentrations. The $32 \% \mathrm{NDF}$ diet used in this experiment allowed for higher efficiency of production and lower feed costs. The practice among dairy farmers to give their cows diets with a high proportion of concentrates, expecting to improve milk production, is not justified by the results of this trial and will certainly result in increased feeding costs and a reduction in potential earnings for the farmer.

As expected, low fiber diets (20 and $26 \%$ ) resulted in reductions in milk fat percentage. These reductions could be an indication of a negative effect on rumen fermentation, which can have long-term negative effects on cow health and longevity in the herd. At current production levels, feeding diets with less than $32 \%$ NDF is not recommended. At higher milk production levels and for cows in early lactation, the potential of such diets is still unknown and merits further study.

\section{LITERATURE CITED}

Bernal, E., 1992. Utilization of Tifton 81 Bermudagrass Silage by Lactating and Nonlactating Dairy Cows as Influenced by Forage Maturity and Dietary Ratios of Forageto-Concentrate, Masters Thesis, Univ. of Florida, Gainesville, FL.

Littell, R. C., R. J. Freund and P. C. Spector, 1992. SAS system for linear models. Third Edition, SAS Institute Inc., Cary, NC.

Mertens, D. R., 1989. Fiber analysis and its use in ration formulation. Proceedings $24^{\text {th }}$ Annual Pacific Northwest Animal Nutrition Conference, Boise, Idaho.

National Research Council, 1988. Nutrient requirements of dairy cattle. Sixth Edition, National Academy Press, Washington, DC.

National Academy Press, and National Research Council, 1981. Effect of environment on nutrient requirements of domestic animals. National Academy Press, Washington, DC.

Ruiz, T. M., 1993. Use of fiber concentrations and digestibilities of various forage species for determining dry matter intake by lactating dairy cows. Ph.D. Dissertation, Univ, of Florida, Gainesville, FL. 
Ruiz, T. M., E. Bernal, L. E. Sollenberger; R. N. Gallaher and C. R. Staples, 1995a. Effect of dietary neutral detergent fiber concentration and forage source on performance of lactating cows. J. Dairy Sci. 78:305.

Ruiz, T. M., B. Rivera and N. Corchado, 1995b. Two feeding systems for lactating dairy cows grazing fertilized grasses. J. Agric. Univ. P.R. 79(3-4):99.

Ugarte, J., R. S. Herrera, R. Ruiz, R. García, C. M. Vásquez y A. Senra, 1983. Los pastos en Cuba: Tomo 2: Utilización. Instituto de Ciencia Animal, La Habana, Cuba.

Varga, G. A., H. M. Dann and V. A. Ishler, 1998. The use of fiber concentrations for ration formulation. J. Dairy Sci. 81:3063. 